\title{
Investigation of the Relationship Between the Sports Status of Secondary School Students and Their Emotional Intelligence Levels
}

\author{
Murat Çelebi ${ }^{1}$ \\ ${ }^{1}$ Faculty of Sports Sciences, Bartın University, Bartın, Turkey \\ Correspondence: Murat Çelebi, Faculty of Sports Sciences, Kutlubey Campus, Bartın University, Bartın, Turkey. \\ E-mail: mcelebi@bartin.edu.tr
}

Received: June 30, 2020

doi:10.5539/ies.v13n10p168
Accepted: August 20, $2020 \quad$ Online Published: September 25, 2020

URL: https://doi.org/10.5539/ies.v13n10p168

\begin{abstract}
The aim of this study is to investigate the sports status and emotional intelligence levels of secondary school students. 1027 secondary school students participated in the research. As a data collection tool in the research; personal information form, parent consent form and voluntary consent form were used. In measuring the emotional intelligence levels of students, a 60-item measurement tool developed by Bar-on, applicable to children and adolescents was used, and the scale was adapted to Turkish by Köksal (2007). Descriptive statistics, ANOVA and t-test techniques were used in the analysis of the data. As a result of the analyses, there was a statistically significant difference in interpersonal, adaptability and positive effect $(p<0.05)$ of the emotional intelligence sub-dimensions and the gender variable. When the emotional intelligence levels of the students were analyzed according to the variable of sports status, a significant difference was observed in the adaptability dimension and in the total score of emotional intelligence in favor of those who exercise sports $(\mathrm{p}<0.05)$. When the emotional intelligence levels of the students were examined according to the class level variable, there were significant differences in the total score of emotional intelligence, stress management and adaptability $(p<0.05)$. Moreover, in the examination of the emotional intelligence levels of the students according to their mother's education levels, a significant difference was found only in the adaptability dimension $(p<0.05)$. For their father's education levels, there was a significant difference in the interpersonal and the adaptability dimensions $(p<0.05)$.
\end{abstract}

Keywords: secondary school, emotional intelligence, sports status

\section{Introduction}

In the world, which witnesses a rapid change process, children to overcome difficulties and obstacles, to be individuals with emotional well-being and high awareness, to behave more harmoniously in their educational life and more consciously in social life may be closely related to their emotional intelligence. Determining this relationship in a healthy way and constantly updating the studies in this direction reveals the importance of emotional intelligence studies (Karabulut, 2012).

Emotional intelligence is defined by researchers in different ways. The concept of emotional intelligence, known for a work published by Salovey and Mayer (1990) was defined as "being able to reflect the feelings and feelings of one's own or others, to distinguish them and to use this knowledge in one's thought and action". Goleman (1995) published his book "Emotional Intelligence" and it became a factor in the international reputation of emotional intelligence. He defined emotional intelligence as "an understanding of one's own emotions, empathy for others' feelings, and the ability to organize their emotions to enrich life". According to Bar-On (1997), who is a psychologist and develops different tools for measuring emotional intelligence, it was defined as "the interaction of emotional, personal and social abilities in a person's ability to succeed in dealing with environmental pressures and desires".

According to the researches, emotional intelligence in children varies between the ages of 11-13 and this variability decreases gradually as the age gets older (Keefer, Holden, \& Parker, 2013). It was observed that children with high emotional intelligence levels felt happier and had higher self-confidence in forming a successful identity (Shapiro, 2017). It is known that the relationship between individuals' emotional intelligence levels and personality traits is high (Sarıkabak, 2016). Children with high emotional intelligence levels can make more logical and effective decisions (Sevdalis, Petrides, \& Harvey, 2007). It is also known that children with high levels of emotional intelligence may be responsible and productive individuals in the future (Shapiro, 2017). 
It can be said that the secondary education period has become determinative about how the children will go to education in their remaining lives, how they will specialize on a profession, and at the same time how they will gain knowledge and skills to guide these ideas. Decisions to be taken in this period can change the way individuals view their selves and their environment. A study by Bender (2006) found that the concept of emotional intelligence affects $7 \%$ of creativity. Therefore, the concept of emotional intelligence may also be related to children's creative thinking skills.

Emotional intelligence is a concept that affects children's lives in many ways. Children with high level of emotional intelligence are individuals who express themselves better, act with their emotions, and more resistant to stress in their social lives (Mayer et al., 2001). In addition, individuals with high level of emotional intelligence have the capacity to think flexibly. Flexible thinking skills are effective on emotional intelligence and emotional balance (Liu, Wang, \& Lü, 2013).

The concept of emotional intelligence is also associated with many disciplines. In addition, emotional intelligence includes many concepts from academic success to success in social life. For example, it has been stated by researchers that sports are an effective concept on the level of emotional intelligence. Sarkabak (2018) describes emotional intelligence in sports as: "The athlete knows himself, his branch and the personal characteristics related to them, knows the emotional state of his opponent and his team mates in individual and team sports, and knows their physical characteristics well, and managing the process by establishing a bond among all these futures". These features may also be effective on secondary school students who continue their development with continuous cognitive and emotional game activities.

When secondary school students can convey their emotions through a healthy communication, analyze the emotional flow well and have the ability to manage the process, their personalities are also affected by this situation and they can set off towards a more successful life. In the secondary education process, emotional intelligence trainings that will be given to students can prepare them for their future lives. Therefore, emotional recognition and evaluation of children are also critical for supporting their vital skills. This study is important to contribute to the literature in terms of determining the emotional intelligence levels of the students who are studying in the secondary education period, class levels, doing sports, and examining the link between parents' education and emotional intelligence levels.

When secondary school students can convey their emotions through a healthy communication, analyze the emotional flow well and have the ability to manage the process, their personalities are also affected by this situation and they can set off towards a more successful life. In the secondary education process, emotional intelligence trainings that will be given to students can prepare them for their future lives. Therefore, emotional recognition and evaluation of children are also critical for supporting their vital skills. This study is important to contribute to the literature in terms of determining and examining the link among the emotional intelligence levels of the secondary education level students, class levels, status of doing sports and parents' education.

\section{Method}

The research was performed based on the relational screening model. 1027 secondary school students who attended the study in different schools in Bartın province in the fall semester of 2019-2020, who were selected among 38,689 primary and secondary school students by simple random method, participated.

In the research, personal information form, parent consent form and voluntary consent form created by the researcher were used as data collection tool. By giving information about the purpose of the research to the students, in order to ensure voluntary participation, the consent of the parent consent form was provided to the parents through the students and the forms were collected from the students whose permission was obtained by the researcher.

\subsection{Bar-On Emotional Intelligence Scale Child and Adolescent Form}

The Bar-On Emotional Intelligence Scale - Child and Adolescent Form scale developed by Bar-On and Parker can be applied to children and young people aged 7-18 and consist of 60 items in total. The scale was adapted to Turkish by Köksal (2007). Cronbach Alpha reliability coefficient of the scale was calculated as 0.91 . The items are evaluated in a 4-point Likert type, ranging from describing me little to describing me very much.

In the analysis of the data, the information about the participant group and other variables of the research were analyzed with descriptive statistical techniques. Independent t-test and one-way analysis of variance (ANOVA) were used in the analysis of the data. The significance level of the data was taken as $(p<0.05)$, and SPSS 25 package program was used to evaluate the data. 


\section{Results}

Table 1. Demographic information of students

\begin{tabular}{cccc}
\hline & Variables & F & $\%$ \\
\hline \multirow{3}{*}{ Gender } & Male & 509 & 49,6 \\
& Woman & 518 & 50,4 \\
\hline \multirow{4}{*}{ Grade Level } & 5th grade & 106 & 10,3 \\
& 6th grade & 316 & 30,8 \\
& 7th grade & 374 & 36,4 \\
& 8th grade & 231 & 22,5 \\
\hline \multirow{4}{*}{ Mother Education } & Literate & 27 & 2,6 \\
& Primary school & 217 & 21,1 \\
& Middle School & 281 & 27,4 \\
& High school & 305 & 29,7 \\
& University & 197 & 19,2 \\
\hline \multirow{5}{*}{ Father Education } & Literate & 22 & 2,1 \\
& Primary school & 151 & 14,7 \\
& Middle School & 220 & 21,4 \\
& High school & 382 & 37,2 \\
& University & 252 & 24,5 \\
\hline \multirow{3}{*}{ Sports Status } & Yes & 629 & 61,2 \\
& No & 398 & 38,8 \\
\hline
\end{tabular}

Demographic information about students was given in Table 1. It was seen that 509 of the students are male and 518 were female. 106 students in 5th grade, 316 in 6 th grade, 374 in 7 th grade, and 231 in 8 th grade were observed.

Table 2. Comparison of students' emotional intelligence sub-dimensions and total scores according to gender variable

\begin{tabular}{|c|c|c|c|c|c|}
\hline & Gender & $\mathrm{N}$ & $\overline{\mathrm{x}}$ & $\mathrm{t}$ & $\mathrm{p}$ \\
\hline \multirow{2}{*}{ Interpersonal } & Male & 509 & 39.2299 & -3.743 & .000 \\
\hline & Woman & 518 & 40.3610 & & \\
\hline \multirow{2}{*}{ Intrapersonal } & Male & 509 & 16.3752 & 1.035 & .301 \\
\hline & Woman & 518 & 16.1544 & & \\
\hline \multirow{2}{*}{ Stress Management } & Male & 509 & 31.9371 & 1.115 & .265 \\
\hline & Woman & 518 & 31.5135 & & \\
\hline \multirow{2}{*}{ Adaptability } & Male & 509 & 30.1473 & 2.181 & .029 \\
\hline & Woman & 518 & 29.4614 & & \\
\hline \multirow{2}{*}{ General Mood } & Male & 509 & 45.8900 & .292 & .770 \\
\hline & Woman & 518 & 45.7741 & & \\
\hline \multirow{2}{*}{ Positive Impression } & Male & 509 & 15.8743 & 2.473 & .014 \\
\hline & Woman & 518 & 15.4170 & & \\
\hline \multirow{2}{*}{ Total EQ } & Male & 509 & 179.4538 & .659 & .510 \\
\hline & Woman & 518 & 178.6815 & & \\
\hline
\end{tabular}

In Table 2, it was observed that there was a statistically significant difference in interpersonal, adaptability and positive effect sub-dimensions of emotional intelligence $(\mathrm{p}<0.05)$. This significant difference was observed to be in favor of women in the inter-personal dimension and in favor of men in the adaptability and positive effect dimensions. There was no significant difference in intrapersonal, stress management, general mood and total score $(\mathrm{p}>0.05)$. 
Table 3. Comparison of the emotional intelligence sub-dimensions and total scores of the students according to sports variable

\begin{tabular}{|c|c|c|c|c|c|}
\hline & Sports Status & $\mathrm{N}$ & $\overline{\mathrm{x}}$ & $\mathrm{t}$ & $\mathrm{p}$ \\
\hline \multirow{2}{*}{ Interpersonal } & Yes & 629 & 39.8188 & \multirow{2}{*}{.152} & \multirow{2}{*}{.879} \\
\hline & No & 398 & 39.7714 & & \\
\hline \multirow{2}{*}{ Intrapersonal } & Yes & 629 & 16.4118 & \multirow{2}{*}{1.783} & \multirow{2}{*}{.075} \\
\hline & No & 398 & 16.0302 & & \\
\hline \multirow{2}{*}{ Stress Management } & Yes & 629 & 31.7615 & \multirow{2}{*}{.252} & \multirow{2}{*}{.801} \\
\hline & No & 398 & 31.6633 & & \\
\hline \multirow{2}{*}{ Adaptability } & Yes & 629 & 30.2719 & \multirow{2}{*}{3.776} & \multirow{2}{*}{.000} \\
\hline & No & 398 & 29.0578 & & \\
\hline \multirow{2}{*}{ General Mood } & Yes & 629 & 46.1351 & \multirow{2}{*}{1.927} & \multirow{2}{*}{.054} \\
\hline & No & 398 & 45.3518 & & \\
\hline \multirow{2}{*}{ Positive Impression } & Yes & 629 & 15.6518 & \multirow{2}{*}{.111} & \multirow{2}{*}{.911} \\
\hline & No & 398 & 15.6307 & & \\
\hline \multirow{2}{*}{ Total EQ } & Yes & 629 & 180.0509 & \multirow{2}{*}{2.120} & \multirow{2}{*}{.034} \\
\hline & No & 398 & 177.5050 & & \\
\hline
\end{tabular}

When Table 3 was examined, a statistically significant difference was observed in the adaptability sub-dimension and total score $(\mathrm{p}<0.05)$. This significant difference was in favor of those who do sports. There was no statistically significant difference in terms of other sub-dimensions.

Table 4. Results of One-Way Variance (ANOVA) analysis of emotional intelligence sub-dimensions and total scores of students according to class level variable

\begin{tabular}{|c|c|c|c|c|c|c|c|}
\hline \multicolumn{2}{|c|}{ Class Level } & Sum of Squares & $\mathrm{df}$ & Mean Square & $\mathrm{F}$ & Sig. & Sig. Difference \\
\hline \multirow{3}{*}{ Interpersonal } & Between Groups & 51.55 & 3 & 17.183 & 0.724 & 0.538 & \\
\hline & Within Groups & 24296.53 & 1023 & 23.75 & & & - \\
\hline & Total & 24348.08 & 1026 & & & & \\
\hline \multirow{3}{*}{ Intrapersonal } & Between Groups & 71.212 & 3 & 23.737 & 2.038 & 0.107 & \\
\hline & Within Groups & 11914.28 & 1023 & 11.646 & & & - \\
\hline & Total & 11985.49 & 1026 & & & & \\
\hline \multirow{3}{*}{ Stress Management } & Between Groups & 436.54 & 3 & 145.513 & 3.958 & 0.008 & \\
\hline & Within Groups & 37606.93 & 1023 & 36.761 & & & $1>4$ \\
\hline & Total & 38043.46 & 1026 & & & & \\
\hline \multirow{3}{*}{ Adaptability } & Between Groups & 234.961 & 3 & 78.32 & 3.087 & 0.026 & \\
\hline & Within Groups & 25954.52 & 1023 & 25.371 & & & $1>4$ \\
\hline & Total & 26189.48 & 1026 & & & & \\
\hline \multirow{3}{*}{ General Mood } & Between Groups & 282.287 & 3 & 94.096 & 2.34 & 0.072 & \\
\hline & Within Groups & 41143.57 & 1023 & 40.219 & & & - \\
\hline & Total & 41425.86 & 1026 & & & & \\
\hline \multirow{3}{*}{ Positive Impression } & Between Groups & 245.356 & 3 & 81.785 & 9.503 & 0 & \\
\hline & Within Groups & 8804.209 & 1023 & 8.606 & & & $1>2.3 .4$ \\
\hline & Total & 9049.566 & 1026 & & & & \\
\hline \multirow{3}{*}{ Total EQ } & Between Groups & 4737.646 & 3 & 1579.215 & 4.522 & 0.004 & \\
\hline & Within Groups & 357272.1 & 1023 & 349.24 & & & $1>4$ \\
\hline & Total & 362009.8 & 1026 & & & & \\
\hline
\end{tabular}

\section{5th Class; 2. 6th Class; 3. 7th Class; 4. 8th Class.}

In Table 4, there was a significant difference in stress management, adaptability and total score. This significant difference is in favor of students in 5th grade between 5th and 8th grades. In the positive impression dimension, a significant difference was observed among the students in the 5 th grade, 6th grade, 7 th grade and 8 th grades, and it was in favor of the 5 th grade $(\mathrm{p}<0.05)$. No significant differences were found in the interpersonal, intrapersonal 
and general mood sub-dimensions $(\mathrm{p}>0.05)$.

Table 5. Emotional intelligence sub-dimensions of students according to mother's education level and one-way variance (ANOVA) analysis results of total score

\begin{tabular}{|c|c|c|c|c|c|c|c|}
\hline \multicolumn{2}{|c|}{ Mother Education Level } & \multirow{2}{*}{$\begin{array}{c}\text { Sum of Squares } \\
38.271\end{array}$} & \multirow{2}{*}{$\frac{\mathrm{df}}{4}$} & \multirow{2}{*}{$\begin{array}{c}\text { Mean Square } \\
9.568\end{array}$} & \multirow{2}{*}{$\begin{array}{c}\mathrm{F} \\
.402\end{array}$} & \multirow{2}{*}{$\begin{array}{l}\text { Sig. } \\
.807\end{array}$} & \multirow[t]{2}{*}{$\begin{array}{c}\text { Sig. } \\
\text { Difference }\end{array}$} \\
\hline & Between Groups & & & & & & \\
\hline \multirow[t]{3}{*}{ Interpersonal } & Within Groups & 24309.809 & 1022 & 23.787 & & & - \\
\hline & Total & 24348.080 & 1026 & & & & \\
\hline & Between Groups & 40.506 & 4 & 10.127 & .866 & .483 & \\
\hline \multirow[t]{3}{*}{ Intrapersonal } & Within Groups & 11944.983 & 1022 & 11.688 & & & - \\
\hline & Total & 11985.490 & 1026 & & & & \\
\hline & Between Groups & 258.513 & 4 & 64.628 & 1.748 & .137 & \\
\hline \multirow[t]{3}{*}{ Stress Management } & Within Groups & 37784.952 & 1022 & 36.972 & & & - \\
\hline & Total & 38043.464 & 1026 & & & & \\
\hline & Between Groups & 575.551 & 4 & 143.888 & 5.741 & .000 & \\
\hline \multirow[t]{3}{*}{ Adaptability } & Within Groups & 25613.927 & 1022 & 25.063 & & & $5>4.3 .2 .1$ \\
\hline & Total & 26189.478 & 1026 & & & & \\
\hline & Between Groups & 227.320 & 4 & 56.830 & 1.410 & .229 & \\
\hline \multirow[t]{3}{*}{ General Mood } & Within Groups & 41198.538 & 1022 & 40.312 & & & - \\
\hline & Total & 41425.858 & 1026 & & & & \\
\hline & Between Groups & 23.963 & 4 & 5.991 & .678 & .607 & \\
\hline \multirow[t]{3}{*}{ Positive Impression } & Within Groups & 9025.602 & 1022 & 8.831 & & & - \\
\hline & Total & 9049.566 & 1026 & & & & \\
\hline & Between Groups & 2284.753 & 4 & 571.188 & 1.623 & .166 & \\
\hline \multirow[t]{2}{*}{ Total EQ } & Within Groups & 359725.006 & 1022 & 351.981 & & & - \\
\hline & Total & 362009.759 & 1026 & & & & \\
\hline
\end{tabular}

\section{Literate; 2. Primary School; 3. Secondary School; 4. High School; 5. University.}

According to Table 5, according to their mother's education levels, a significant difference was found in the adaptability dimension in favor of university graduates among the education levels of literate, primary, secondary and high school $(\mathrm{p}<0.05)$.

Table 6. Emotional intelligence sub-dimensions of students according to father's education level and results of one-way variance (ANOVA) analysis of total points

\begin{tabular}{cccccccc}
\hline \multirow{2}{*}{ Father Education Level } & Sum of Squares & df & Mean Square & F & Sig. & $\begin{array}{c}\text { Sig. } \\
\text { Difference }\end{array}$ \\
\hline \multirow{4}{*}{ Interpersonal } & Between Groups & 234.549 & 4 & 58.637 & 2.485 & .042 & \\
& Within Groups & 24113.531 & 1022 & 23.594 & & & $5>3$ \\
& Total & 24348.080 & 1026 & & & & \\
\hline \multirow{5}{*}{ Intrapersonal } & Between Groups & 72.731 & 4 & 18.183 & 1.560 & .183 & \\
& Within Groups & 11912.759 & 1022 & 11.656 & & & - \\
& Total & 11985.490 & 1026 & & & & \\
\hline \multirow{3}{*}{ Stress Management } & Between Groups & 456.756 & 4 & 114.189 & 3.105 & .015 & \\
& Within Groups & 37586.708 & 1022 & 36.778 & & & $5>2$ \\
& Total & 38043.464 & 1026 & & & & \\
\hline \multirow{5}{*}{ Adaptability } & Between Groups & 471.355 & 4 & 117.839 & 4.683 & .001 & \\
& Within Groups & 25718.124 & 1022 & 25.165 & & & $5>2$ \\
& Total & 26189.478 & 1026 & & & & \\
\hline \multirow{2}{*}{ General Mood } & Between Groups & 178.961 & 4 & 44.740 & 1.109 & .351 & \\
& Within Groups & 41246.896 & 1022 & 40.359 & & & - \\
& Total & 41425.858 & 1026 & & & & \\
\hline
\end{tabular}




\begin{tabular}{ccccccc}
\hline & Between Groups & 20.670 & 4 & 5.167 & .585 & .674 \\
Positive Impression & Within Groups & 9028.896 & 1022 & 8.835 & & \\
& Total & 9049.566 & 1026 & & & \\
& Between Groups & 5543.483 & 4 & 1385.871 & 3.973 & .003 \\
\multirow{2}{*}{ Total EQ } & Within Groups & 356466.275 & 1022 & 348.793 & & $5>3.2$ \\
& Total & 362009.759 & 1026 & & & \\
\hline
\end{tabular}

1. Literate; 2. Primary School; 3. Secondary School; 4. High School; 5. University.

In the Table 6, according to the education levels of the fathers of the students, significance was found in the intrapersonal dimension in favor of the university graduates among university and secondary school graduates, in the favor of the university graduates among primary and university graduates in the stress management and adaptability dimension, and in the total score of those whose father was university graduates among primary and secondary school graduates $(\mathrm{p}<0.05)$.

\section{Discussion}

In emotional intelligence sub-dimensions of secondary school students; there was a statistically significant difference in interpersonal, adaptability and positive impression sub-dimensions $(\mathrm{p}<0.05)$. According to researchers, women are generally found to be better than men to understand and manage emotions. Toronto (1997) said that both sexes have equal levels of emotional intelligence. However, as a result of the emotional intelligence test conducted on 4500 men and 3200 women consisting of Canadians and Americans, it was concluded that women were more successful in interpersonal skills than men and men had a stronger self-esteem skill compared to women (Yurdakavuştu, 2012). While talking about these skills, Petrides and Furnham (2000) stated that women's empathy levels were higher than men. The result of Petrides and Furnham (2000) is similar to our findings. The reason for the high scores of women in the interpersonal sub-dimension can be explained by the fact that women are more successful in interpersonal relationships, are a good listener and are more capable of understanding emotions of other individuals. However, it was known that women more often complain of higher levels of depression than men. While any situation that bothers women is not easily overcome by them, it was observed that men were more successful in doing this (Oral, 2011). Therefore, this situation can be explained by the higher adaptability scores of male students than female students. Because individuals with high level of adaptability are more successful in dealing with the problems encountered and finding solutions (Bar-On, 2000).

While Goleman (2003) talked about the pure high emotional intelligence of men, he talked about people with responsibilities and about being at peace with themselves or the social world they live in. These concepts can also be explained by the fact that male students want to have more positive effect than what they have. In other studies, conducted in the field, it is possible to reach conclusions stating that there is no significant difference between the concept of gender and emotional intelligence, and the scores of the two groups are very close to each other (Chan, 2004; Hopkins \& Bilimoria, 2008; Rastegar \& Memarpour, 2009). It was observed that there was a statistically significant difference in secondary education students' adaptability dimension and emotional intelligence total scores according to the sports status variable $(p<0.05)$. Researches showed that as a result of individuals' participation in sports activities, they had improved in many ways (Hekim, 2015). In a similar study conducted in the field, Amado-Alonso et al. (2019) stated that children who regularly exercised sports had high emotional intelligence levels. We could state that emotional intelligence skills could be improved through sports and many studies agreed on this issue (Kamin, 2000; Costarelli, 2009; Sarıkabak, Eyüboğlu, \& Ayranc1 2018). Individuals participating in sports activities are effective and happy to adapt to new situations, to cope with and solve problems, as well as to cope with daily needs.

According to the grade level variable of secondary education students, there was a significant difference in the total scores of emotional intelligences, stress management and adaptability dimensions $(p<0.05)$. Emotional intelligence begins to develop from infancy. Craig (1989) stated that babies younger than 6 months could experience less specialized emotions in the form of pleasure, peace and anger, and different emotions such as joy, danger or anger after 6 months. In most of the studies, it was stated that children between the ages of 2-3 years can recognize many emotions, but have not been successful in showing some facial expressions (Ar1 et al., 1995; Gross \& Ballif 1991; Laksman \& Whissel, 1991; Walden \& Field, 1982; Tuğrul, 1999). With the advancement of the ages of the students, their level of emotional intelligence, their competencies related to the development of school, environment and social life increase. According to UNESCO, the period between the ages of 10-12 for girls and the period between the ages of 11-13 for boys is considered as preliminary period. It is known that individuals experience complex feelings and tend to be selfish towards their environment during this period. Therefore, there 
may be a difference in terms of emotional intelligence levels among students in 5th and 8 th grades. One of the most important reasons for this difference could be evaluated as the students' having complex emotions in the 8th grade, which is seen as a transition to adolescence.

There were statistically significant differences in comparing emotional intelligence levels and mother and father education levels of secondary school students $(\mathrm{p}<0.05)$. Our research findings were in line with the results of Bender (2006) and Kurtıl (2009). Bender (2006) examined the relationship between emotional intelligence and creativity among art and business students, and found that emotional intelligence levels had a relationship that will make a significant difference with the education levels of the parents.

As a result of comparing the education level variable with the emotional intelligence levels of the secondary school students, the emotional intelligence levels of the university and college graduate mothers' children were higher. The results of Kuzu and Eker (2010) and Harrod and Scheer (2005) supported our findings. Despite our research findings, some researchers stated that individuals with low levels of maternal education had higher levels of emotional intelligence. They said that the reason for this situation is that mothers spend more time with their children in their home environment than working life, as they could support them more in their emotional development processes (Sarkabak et al., 2018).

As a result of the research, significant differences were found according to the gender, sports status, the grade level, the education level of the mother and the father. The fact that emotional intelligence is an improvable concept, and is important in terms of increasing supportive education during the education periods. It can contribute to the development of emotional intelligence levels of students by considering different dimensions that will improve intelligence in education. Students who are aware of their own emotions can guide their lives by understanding their friends' emotions and establishing a healthy communication with them. This can make students emotionally stronger. It can be suggested that the sportive activities within the educational activities should be planned in a way to improve the affective behavior of the children.

\section{References}

Amado-Alonso, D., León-del-Barco, B., Mendo-Lázaro, S., Sánchez-Miguel, P. A., \& Iglesias Gallego, D. (2019). Emotional Intelligence and the Practice of Organized Physical-Sport Activity in Children. Sustainability, 11(6), 1615. https://doi.org/10.3390/su11061615

Bar-On, R. (1997). The Emotional Quotient Inventory (EQ-i): Technical manual. Toronto, Canada: Multi-Health Systems, Inc.

Bar-On, R. (2000). BarOn Emotional Quotient Inventory. Youth Version Technical Manual. Toronto; North Tonawanda, NY: Multi-Health Systems Inc.

Bender, M. T. (2006). Emotional intelligence and creativity relations in students of art education (Unpublished doctoral dissertation). Dokuz Eylül University, Institute of Educational Sciences, İzmir, Turkey

Büyüköztürk, Ş., Çakmak, E. K., Akgün, Ö. E., Karadeniz, Ş., \& Demirel, F. (2017). Scientific Research Methods. Pegem Citation Index, 1-360.

Chan, D. W. (2004). Perceived emotional intelligence and self-efficacy among Chinese secondary school teachers in Hong Kong. Personality and Individual Differences, 36(8), 1781-1795. https://doi.org/10.1016/j.paid.2003.07.007

Costarelli, V., \& Stamou, D. (2009). Emotional Intelligence, Body Image and Disordered Eating Attitudes in Combat Sport Athletes. Journal of Exercise Science and Fitness, 7(2), 104-111. https://doi.org/10.1016/S1728-869X(09)60013-7

Goleman, D. (1995). Emotional Intelligence: Why it can matter more than IQ? New York: Bantam Books.

Goleman, D. (2003). Emotional intelligence-why is it more important than IQ? (B. Seçkin Yüksel, Transl.) İstanbul: Varlik.

Hekim, M. (2015). Physical Activity and The Importance of Sport in Prevention of Childhood Obesity. Journal of International Social Research, 8(37).

Hopkins, M. M., \& Bilimoria, D. (2008). Social and emotional competencies predicting success for male and female executives. Journal of Management Development, 27(1), 13-35. https://doi.org/10.1108/02621710810840749

Kamin, D. (2000). The Relationship Between Emotional Intelligence Levels and Performance Statistics of NCAA Division L-Caliber Baseball Players. Southern Connecticut State University. 
Karabulut, A. (2012). Emotional Intelligence: The Baron Scale Adaptation (Unpublished Master Thesis). Dokuz Eylül University, Institute of Educational Sciences. Izmir.

Keefer, K. V., Holden, R. R., \& Parker, J. D. A. (2013). Longitudinal assessment of trait emotional intelligence: measurement invariance and construct continuity from late childhood to adolescence. Psychological Assessment, 25(4), 1255-1272. https://doi.org/10.1037/a0033903

Köksal, A. (2007). Program development study for developing emotional intelligence in gifted children (Unpublished doctoral dissertation). Istanbul University Institute of Social Sciences, Istanbul, Turkey

Liu, Y., Wang, Z., \& Lü, W. (2013). Resilience and affect balance as mediators between trait emotional intelligence and life satisfaction. Personality and Individual Differences, 54(7), 850-855. https://doi.org/10.1016/j.paid.2012.12.010

Oral, E. (2011). Doesn't Happen Without EQ.

Petrides, K. V., \& Furnham, A. (2000). Gender Difference in Measured and Self-Estimated Trait Emotional Intelligence. Sex Roles, 42(5/6), 449-461. https://doi.org/10.1023/A:1007006523133

Rastegar, M., \& Memarpour, S. (2009). The relationship between emotional intelligence and self-efficacy among Iranian EFL Teachers. System, 37(4), 700-707. https://doi.org/10.1016/j.system.2009.09.013

Salovey, P., \& Mayer, J. D. (1990). Emotional intelligence. Imagination, Cognition, and Personality, 9(3), 185-211. https://doi.org/10.2190/DUGG-P24E-52WK-6CDG

Sarkabak, M. (2016). The effect of positive and negative feedback on the maximal voluntary contraction level of the Biceps Brachii muscle in athletes of different personality types (Unpublished doctoral dissertation). Sakarya University, Institute of Educational Sciences, Sakarya, Turkey. https://doi.org/10.1177/0031512516673752

Sarıkabak, M. (2018) Emotional Intelligence and Sport. In F. Yamaner, \& E. Eyuboğlu (Eds.), Human, Social and Sports Science Research Examples (pp. 401-408). Ankara: Nobel Academic Publishing.

Sarıkabak, M., Eyuboğlu, E., \& Ayranc1, M. (2018). Investigation of the Effect of Emotional Intelligence Levels of Bocce (Petanque) Athletes on Academic Procrastination Behaviors. International Journal of Cultural and Social Studies (IntJCSS), 4(1), 163-177.

Sevdalis, N., Petrides, K. V., \& Harvey, N. (2007). Trait emotional intelligence and decision-related emotions. Personality and Individual Differences, 42(7), 1347-1358. https://doi.org/10.1016/j.paid.2006.10.012

Shapiro, L. E. (2017). Raising a child with high EQ (Ü. Kartal Transl.). İstanbul.

Tuğrul, C. (1999). Clinical Psychiatry. Varlık Publications.

Yurdakavuştu, Y. (2012). Emotional Intelligence and Social Skill Levels in Primary School Students. Dokuz Eylül University, Institute of Educational Sciences, Izmir.

\section{Copyrights}

Copyright for this article is retained by the author(s), with first publication rights granted to the journal.

This is an open-access article distributed under the terms and conditions of the Creative Commons Attribution license (http://creativecommons.org/licenses/by/4.0/). 